\title{
SOBRE A DECADÊNCIA DE SANTA CATARINA
}

\author{
THE DECLINE OF SANTA CATARINA
}

\begin{abstract}
Ricardo Machado*
OLIVEIRA, Henrique Luiz Pereira; SALOMON, Marlon. A decadência de Santa Catarina. Florianópolis: UFSC, 2010. 108 p.

Já em seu título, os autores Marlon Salomon e Henrique Luiz Pereira Oliveira, parecem anunciar um lamento ou a denúncia do empobrecimento em algum lugar do passado de Santa Catarina. No entanto, distante disto, o livro "A Decadência de Santa Catarina", aborda o problema da decadência de saberes que possibilitaram práticas de governo. Para isso, os autores analisaram as fontes do século XVIII e XIX em sua historicidade, demonstrando que aquilo que os historiadores tradicionalmente leram como anúncio da decadência da província de Santa Catarina, era o fim de uma prática de governo centrada na ocupação do território para o surgimento da população como problema. Mesmo que muito próxima de uma história apresentada por Foucault em sua "governamentalidade", trata-se de uma pesquisa extremamente inovadora no tratamento das fontes e ousada em sua abordagem historiográfica.

A ousadia desta pesquisa não se restringe ao título da obra. Nas breves 107 páginas que compõem o livro, há de forma teórica e metodologicamente sustentada, críticas às interpretações dadas pela historiografia sobre este período em Santa Catarina. Vamos a algumas delas: a) crítica à uma história moralista, que se apropria da dicotomia preguiça/trabalho como elementos étnicos, fora de sua própria historicidade; b) crítica ao conceito de economia de subsistência, por unificar sociedades anteriores ao capitalismo que não podemos traçar nenhum paralelo; c) crítica à noção de imigração açórico-madeirense ainda no século XVIII, pois para os autores é preciso distinguir o deslocamento de súditos dos
\end{abstract}

* Doutorando no Programa de Pós-Graduação em História da Universidade Federal de Santa Catarina (UFSC). E-mail: ricardomachado1982@gmail.com 
processos de imigração da segunda metade do século XIX; d) crítica à unidade temporal da chamada "imigração alemã", na medida que as ocupações de São Leopoldo e São Pedro de Alcântara nos anos 1820 estão em descontinuidade com a imigração de alemães após 1850; e) crítica à noção de "casais" açorianos no século XIX; f) crítica à uma interpretação que explica a imigração para no Brasil império somente a partir de seus condicionantes econômicos.

A estrutura do livro é marcada claramente por sua definição metodológica, na medida em que os capítulos já ilustram a historicidade das séries documentais e sua descontinuidade. Por isso, em suas páginas não se revela a empresa de construir uma unidade naquilo que tradicionalmente chamamos de história de Santa Catarina, mas justamente, busca demonstrar o que há de mais descontinuo nestas séries e que durante muito tempo foi ignorado pela historiografia.

Primeiramente, os autores abordam "a fortificação e a emergência do deslocamento de súditos", onde o problema de governo está centrado na soberania através da defesa e conservação do território. Foi em meados do século XVIII que a província de Santa Catarina aparece como território a ser ocupado para o deslocamento dos súditos, neste caso, a acomodação dos “casais" açorianos surge como mecanismo para garantir o território e a produção de víveres para o sustento das fortalezas. Aqui os autores fazem distinções fundamentais: o deslocamento de súditos não pode ser confundido com imigração; da mesma forma que a doação de sesmarias como mecanismo de ocupação do território, não está em continuidade com a noção de propriedade privada, pois estão dispostas em conceitos políticos e estratégias de governo completamente distintos. Para eles, "fortalecer uma povoação e fortificar pontos que num território desenham um sistema de defesa são estratégias complementares. Os fortes e as fortalezas são seus correlatos bélico-arquitetônico" (p. 15). Nesta concepção de governo, é o corpo dos súditos que é apropriado, sua própria vida, como instrumento da soberania. Por isso, a família é tida modelo, pois é ao rei que o súdito precisa se submeter, ou seja, "os corpos eram apenas peças na maquinaria de defesa do território, como o eram os canhões e as fortalezas" (p. 16). Esta relação também é materializada na forma em que a propriedade de terra é compreendida, pois neste momento é tida como uma concessão do soberano, por isso, marcada por sua provisoriedade.

Salomon e Oliveira lêem o longo lamento dos historiadores a respeito da pobreza dos habitantes de Santa Catarina no final do século XVIII, como elemento de ruptura entre as formas de governabilidade. A decadência de Santa Catarina, apontada pelas fontes após 1770 é apresentada como a crítica de um mecanismo e o último suspiro da soberania como prática de governo. Assim, os elementos, como a doação de sesmarias, que anteriormente definiam as regras da ocupação do território passam a ser vistos como as causas de sua decadência. 
É justamente o aparecimento desta crítica, o acontecimento necessário para a desobstrução que permitiu o aparecimento de um governo das populações.

No capítulo "governo da população e a emergência da imigração" os autores, tomam a Memória de Abrantes de 1846 e a Lei de Terras de 1850 como materialidade deste limiar, onde o bom governo passa significar tornar a população e o espaço economicamente úteis. Não mais a acomodação de súditos e a doação de sesmarias, mas a imigração e o aparecimento da propriedade privada. Foi através da defesa da imigração que a população torna-se objeto de administração e de conhecimento, e sobretudo, sujeito de necessidades e de aspirações. Isto implicou um novo olhar para o espaço e com isso a constituição de novos saberes, dentre eles a geografização do espaço. Se a engenharia militar tinha por objetivo proteger e impedir o acesso de pessoas a determinados lugares, a agrimensura e a engenharia civil aparecerem neste momento como a possibilidade de demarcar territórios, definir limites. Não mais para isolá-los, mas para estabelecer comunicações e comércio. Segundo os autores, espaço para o século XIX não é mais aquele que deve ser fechado, mas sim, aquele que deve ser aberto, pois governar a população passa a ser animar sua atividade econômica e possibilitar o aumento da população. Na medida em que o espaço foi objeto definição, vemos o surgimento do indivíduo. No governo soberano, os casais, ou melhor, as famílias eram objetos de governo, mas no decorrer do século XIX é o indivíduo passa a ser o objeto de controle, pois é ele que passa a representar a unidade de controle estatístico, de análise política e por isso de domínio e intervenção. Este elemento novo, chamado de "imigrante", que passou a ser individualizado, é que se constituiu como uma população. Foi somente a Lei de Terras de 1850, que tornou as terras públicas e pertencentes ao Estado, sendo que, este por sua vez, deveria ser responsável em vendê-las, mas tendo a preocupação com a sua medição, demarcação e de situá-las em lugares acessíveis, permitindo o aumento da população.

Com isso estaremos diante da introdução da mão de obra livre e a constituição de uma economia capitalista. O governo das populações, demarcando o espaço permitiu atribuição a um valor econômico da terra. Isto foi um elemento fundamental para constituição de indivíduos economicamente úteis. Assim, "o discurso sobre o valor do trabalho, sobretudo entre os imigrantes alemães, tornou-se um importante dispositivo de produção de subjetividade" (p. 95).

É neste ponto em que este livro torna-se fundamental para os estudos de processos de imigração para o sul do país. Para os autores, a imigração para o sul do Brasil na segunda metade do século XIX inscreve-se como dispositivo político do governo das populações. Esta nova forma de governo empreendida é que possibilitou mudanças nas noções de trabalho e de propriedade. Assim, este livro apresenta a possibilidade de produzir uma escrita da história que 
investe profundamente na interpretação das fontes, mas através dela produz um pensamento novo que coloca em questão o próprio estatuto da história e da verdade.

Resenha recebida em outubro de 2011. Aceita em março de 2012. 